\title{
Isolation and Mophological Identification of Endophytic Fungi from Moringa Plant (Moringa oleifera Lam.)
}

\author{
Hasnadhiazahra Rohadi ${ }^{1 *}$, Nuraeni Ekowati ${ }^{1}$,Moh. Ilyas ${ }^{2}$ \\ ${ }^{1}$ Faculty of Biology, Jenderal SoedirmanUniversity \\ ${ }^{2}$ Research Center for Biology, Indonesian Institute of Sciences (LIPI) \\ *Email: Hasnadhiazahra14@gmail.com
}

\begin{abstract}
Article History :
Submitted: $28 / 08 / 2019$ Accepted : 11/11/2019
\end{abstract}

\begin{abstract}
Moringa oleifera Lam. is a small, perennial tree which belongs to moringaceae family. This plant is widely known for their nutritional and medicinal purposes. They can associate with microorganisms showing beneficial symbiosis called as endophytic microorganism. Endophytic fungi is microorganism capable of living within the plant tissues without harming their host. This study was aimed for obtaining pure culture of fungal endophytes from $M$. oleifera and then identifying them based on morphological identification. The morphological identification was done by observing both macro- and micro- morphological characteristics of the endophytic fungi. Twenty endophytic fungi were isolated from lamina, petiole and stem of M. oleifera. The genus obtained were Cladosporium, Colletotrichum,Fusarium, Phomopsis, Phyllosticta, white mycelia sterilia and black mycelia sterilia (Dematiaceae).

Keywords: endophytic fungi; identification; isolation; morphology; Moringa oleifera Lam.
\end{abstract}

\section{INTRODUCTION}

Fungi are eukaryotic organisms that are heterotrophic which means that they obtain carbon and energy from other microorganism. Also, some of them are biotrophic which means that they obtain their nutrients from a living host, while others fungi are called saprotrophs because they obtain their nutrients from dead plants or animals, and some fungi infect the living host plant or animal but they kills them in order to obtains the nutrients, it is called necrotrophs (Carris et al., 2012). Alexopoulos et al. (1996) stated that fungi are mostly reproduced by spores, non chlorophyllus organisms, and have a body composed of filamentous, branched, somatic structure called hyphae. Most fungi associated with plants are an important group of plant pathogens. But $10 \%$ of the fungi can colonize in the healthy living plants, which has benefits symbiosis called endophytic microorganism (Carris et al., 2012).

Various types of plants especially the medicinal plants can be used as the hosts for endophytic fungi. An endophytic fungus from medicinal plants is a source of beneficial secondary metabolites. It also can produced active compounds which are potential as a materials for producing modern medicine (Widowati et al., 2016).

Many researches has been reported that endophytic fungi which were isolated from medicinal plants could produce secondary metabolites which is useful for health and also as biological control to protect the plants from pathogen and disease (Ribeiro et al., 2012). Muscodor albus is an endophytic fungus which were isolated from Cinnamomum zeylanicum, according to Ezra et al. (2004) stated that this fungal has the ability to produce a mixture of volatile organic compounds and has a wide antimicrobial spectrum. The morphological identification is done by observing the macro- and micro characteristics to determine the genus of the fungal isolates. The objective of this study is to identifying the morphological characteristics of endophytic fungi.

\section{MATERIAL DAN METHOD}

\section{Collection of Moringa Plant}

Moringa oleiferaplants were obtained from the backyard of Indonesian Science Center (LIPI) located in Cibinong, Bogor, Jawa Barat. The healthy Moringa plants part were taken from its tree. The plant was stored into plastic bag for fungal endophyte isolation at the micology laboratory, Indonesian Culture Collection (InaCC), Indonesian Institute of Sciences (LIPI), Cibinong, Bogor, Jawa Barat.

\section{Isolation of Endophytic fungi from Moringa}

The endophytic fungi was isolated from three plant parts of Moringa oleifera Lam. i.e. lamina, petiole, and stem. The plant sample was rinsed by the tap water for removed the debris which were coated in the surface of the plant sample for about 10 minutes long. Then cut the plant samples into 2-3 $\mathrm{cm}$ long and surface sterilized it by washed all the cuts plant samples used distilled water, then immersed it with $70 \%$ ethanol for $30 \mathrm{~s}$, and followed by put it into $5.25 \%$ sodium hypoclorite $(\mathrm{NaOCl})$ solution for $30 \mathrm{~s}$, before finally washed it into the sterile distilled water and dried it. After that the surface sterilized plant sample immediately put into the Petri dish with MEA medium,then incubated in 
room temperature for 7 days. The rejuvenation of the fungal endophyte were done by transferred each of the fungal colonies into a new PDA medium and incubated it for about 5-7days.

\section{Morphological Identification of Endophytic Fungi}

The endophytic fungi cultures were morphologically identified by observed the cultures morphology both macro- and micro- characteristic. The macromorphological characteristics observed included the color of the colony, texture of colony, and the surface of the colony. The microscopic morphological observation were done by smeared the endophytic fungal isolates on the slide glass + cover and stained with lactophenol cotton blue and examined under the light microscope. The result morphological identification result was compared the observed characteristics (macro and micromorphological characteristics) with the reference available.

\section{Data Analysis}

The results of the data obtained were analyzed using descriptive methods; each macro- and micromorphological identification results of endophytic fungi are described.

\section{RESULT AND DISCUSSION}

Isolation of Fungal Endophytes Inhabiting $M$. oleifera

Totally 20 strains of endophytic fungi were isolated from 3 sample of moringa plant. The endophytic fungi isolated from leaves of moringa plant 1 were five isolates (ML1A-1, ML1A-2, ML1B-1, ML1C-1, ML1C-2), endophytic fungi from moringa plant 2 leave were five isolates (ML2A-1, ML2A-2, ML2B-1, ML2C-1, ML2X-1), and from the lamina of moringa plant 3 were three isolates (ML3A-1, ML3B-1, ML3C-1). The endophytic fungi isolated from the petiole of moringa plants 1 was one isolate (MP1C-1), while the endophytic fungi from the petiole of moringa plants 2 were five isolates (MP2A-1, MP2C-1, MP2X-1, MP2X-2, MP2X-3). The stem part which was isolated from three different moringa plants, show only one isolate obtained from the stem of moringa plants 1 (MS1A-1). There is no growth showed in the petiole and stem of moringa plants 3 . Therefore the highest amount of endophytic fungal isolates were obtained from the moringa plants 2 with the total amount of isolates was 10 isolate.

Table 1. The Morphological Characterestic of Endophytic Fungi Isolated from Each Part of Moringa Plant Sample

\begin{tabular}{|c|c|c|c|c|c|c|c|c|}
\hline Plants & $\begin{array}{c}\text { Sample } \\
\text { part }\end{array}$ & Isolate & $\begin{array}{l}\text { Colony } \\
\text { form }\end{array}$ & $\begin{array}{l}\text { Surface } \\
\text { texture }\end{array}$ & $\begin{array}{l}\text { Colony } \\
\text { Color }\end{array}$ & Hyphae & $\begin{array}{l}\text { Conidia } \\
\text { shape }\end{array}$ & Fungal Taxa \\
\hline \multirow{7}{*}{ Moringa 1} & \multirow{5}{*}{ Lamina } & ML1A-1 & Irregular & Wolly & White & Septate & Ellipse & Colletotrichum \\
\hline & & ML1A-2 & Filamentous & Wolly & White & Septate & Ellipse & Colletotrichum \\
\hline & & ML1B-1 & Filamentous & $\begin{array}{c}\text { Wrinkled/ } \\
\text { Velvety }\end{array}$ & $\begin{array}{c}\text { Black to } \\
\text { greyish }\end{array}$ & Septate & $\begin{array}{c}\text { Cylindrica } \\
1\end{array}$ & Cladosporium \\
\hline & & ML1C-1 & Irregular & Wolly & Black & Septate & Ellipsoid & Phyllosticta \\
\hline & & ML1C-2 & Irregular & Wolly & $\begin{array}{c}\text { Black to } \\
\text { greyish }\end{array}$ & Septate & Ellipsoid & Phyllosticta \\
\hline & Petiole & MP1C-1 & Irregular & Cottony & $\begin{array}{c}\text { White to } \\
\text { brown to } \\
\text { yellow }\end{array}$ & Septate & Half moon & Fusarium \\
\hline & Stem & MS1A-1 & Filamentous & Cottony & White & Septate & - & $\begin{array}{c}\text { White mycelia } \\
\text { sterilia }\end{array}$ \\
\hline \multirow{9}{*}{ Moringa 2} & \multirow{5}{*}{ Lamina } & ML2A-1 & Filamentous & Wolly & $\begin{array}{l}\text { Greyish } \\
\text { to brown }\end{array}$ & Septate & Ellipse & Colletotrichum \\
\hline & & ML2A-2 & Filamentous & Cottony & White & Septate & Ellipse & Colletotrichum \\
\hline & & ML2B-1 & Filamentous & Wolly & $\begin{array}{l}\text { Greyish } \\
\text { to brown }\end{array}$ & Septate & Ellipse & Colletotrichum \\
\hline & & ML2C-1 & Irregular & Wolly & White & Septate & Ellipsoid & Phylosticta \\
\hline & & ML2X-1 & Filamentous & Wolly & White & Septate & Ellipse & Colletotrichum \\
\hline & \multirow{4}{*}{ Petiole } & MP2A-1 & Filamentous & Wolly & White & Septate & Ellipse & Colletotrichum \\
\hline & & MP2C-1 & Irregular & Wolly & Black & Septate & Ellipsoid & Phyllosticta \\
\hline & & MP2X-1 & Filamentous & Wolly & White & Septate & Ellipse & Phomopsis \\
\hline & & MP2X-2 & Irregular & Wolly & $\begin{array}{l}\text { Grey to } \\
\text { green to } \\
\text { brown }\end{array}$ & Septate & - & $\begin{array}{c}\text { Black mycelia } \\
\text { sterilia } \\
\text { (Dematiaceae) }\end{array}$ \\
\hline
\end{tabular}


BioEksakta: Jurnal Ilmiah Biologi Unsoed

Volume 1, Nomor 2 (2019): 123-126

\begin{tabular}{ccccccccc}
\hline Plants & $\begin{array}{c}\text { Sample } \\
\text { part }\end{array}$ & Isolate & $\begin{array}{c}\text { Colony } \\
\text { form }\end{array}$ & $\begin{array}{c}\text { Surface } \\
\text { texture }\end{array}$ & $\begin{array}{c}\text { Colony } \\
\text { Color }\end{array}$ & Hyphae & $\begin{array}{c}\text { Conidia } \\
\text { shape }\end{array}$ & Fungal Taxa \\
\hline & MP2X-3 & Filamentous & Wolly & $\begin{array}{c}\text { Whitish } \\
\text { to brown }\end{array}$ & Septate & Ellipse & Colletotrichum \\
\cline { 2 - 8 } Moringa 3 & Lamina & ML3B-1 & Filamentous & Wolly & $\begin{array}{c}\text { grey to } \\
\text { brown } \\
\text { grey }\end{array}$ & Septate & Ellipse & Colletotrichum \\
& ML3C-1 & Filamentous & Wolly & White & Septate & Ellipse & Colletotrichum \\
\hline
\end{tabular}

Based on the morphological characteristics observation (Table 1) obtained, the total 10 isolates found in all three moringa plant show identical morphology characteristics. Some of the isolate which show an identical morphological characteristics are ML1A-1, ML1A-2, ML2A-1, ML2A-2, ML2B-1, ML2X-1, MP2A-1, MP2X-3, ML3B-1 and ML3C-1. The colony morphology characteristic of these isolate are have filamentous colony form, wolly surface texture, the colony color relatively white-grey and some of them is blackbrown, the conidia shape is ellipse (Figure 1.), forming sclerotia and they have septate hyphae. Thus characteristics are similar to the characteristics of Colletotrichum sp. mentioned in Song et al. (2016) study namely, slow growth colony, the mycelia color is white to grey and then become black to brown, have septate hyphae, and the conidia is 1 celled conidia with ovoid or ellipse shape.

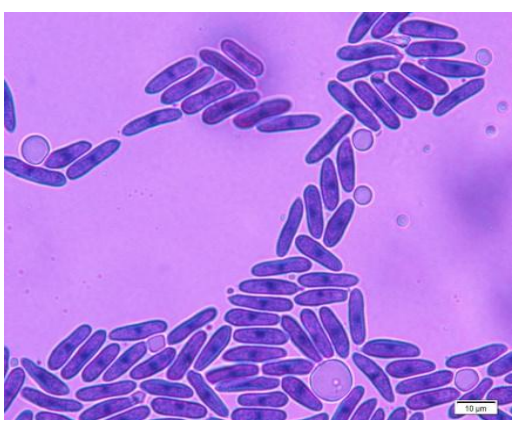

Figure 1. Microscopic Morphology of Endophytic Colletotrichum under Light Microscope with 1000X Magnification

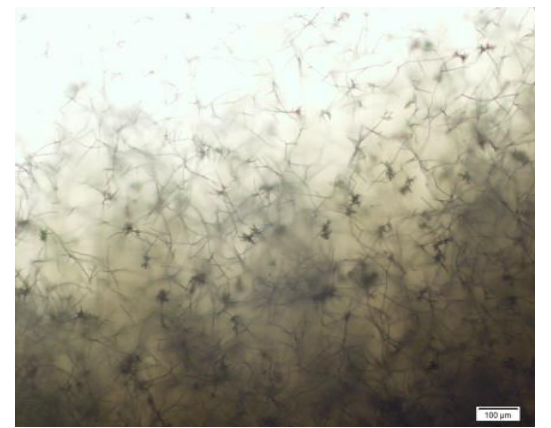

Figure 2. Microscopic Morphology of Endophytic of Cladosporium under LightMicroscope with 100X Magnification
Endophytic fungal isolate ML1B-1 show relatively slow growth colonies with colony color deep green to black. They have wringkled or velvety surface texture and have filamentous colony form, and have cylindrical or elipse conidia shape. The ramoconidia are presents (Figure 2). Based on these characteristic it can be distinguished as Cladosporium sp. According to Bensch et al. (2012) stated that morphological features of Cladosporium sp. are have septate hyphae with smooth, branched, subhyaline, thin walled and sometimes become thick walled with age. The conidia form of these taxa is mostly cylindrical or filiform. The conidia appear in chains and branched, ramoconidia is present. Isolate ML1C-1, ML1C-2, ML2C-1, MP2C-1, and ML3A1 all show similar morphological characteristic namely, have Irregular colony formation, wolly surface structure, black to grey to deep green colony color, septate hyphae and forming sclerotia. These characteristics are similar to the Phyllosticta sp. according to Guarnaccia et al. (2017) the characteristic of Phyllosticta sp. are colonies appear flat, irregular, woolly, initially have white colony color with abundant mycelium, and later gradually become dark green to black with age, and on the undulate margin appeared white hyphae. The reverse colony color is dark green to black, and have ellipse conidia shape and have epiphyllous pycnidium. The isolate MP2X-1 (Phomopsis sp.), based on the Table 1, have a characteristics namely, Irregular colony formation, wolly surface structure, have yellowish to brown colony color, septate hyphae, and ellipse conidia form. These characteristics are similar to the characteristic of Phomopsis mentioned in the result of Nuryadi et al. (2016); Živković et al. (2007), the characteristic are wolly surface structure, have aerial hyphae, whiteyellow-brown colony color, and ellipse conidia shape. The isolate MP2X-2 and MS1A-1 show no conidia or lacking in sporulating structure and included to mycelia sterilia.

\section{CONCLUSION}

Based on the morphology identification of endophytic fungi from Moringa oleifera plant, 20 isolates of endophytic fungi were obtained, which can be grouped into genera Cladosporium, Colletotrichum, Fusarium, Phomopsis, Phyllosticta, white mycelia sterilia and black mycelia sterilia (Dematiaceae). 


\section{ACKNOWLEDGEMENT}

High appreciation is addressed to Microbiology division of Indonesian Culture Collection (InaCC), Research Center for Biology, Indonesian Institute of Sciences (LIPI) for providing facility, labs, equipments, and support for conducting this work. This study was financially supported by Research Center for Biology, Indonesian Institute of Sciences (LIPI) through DIPA project.

\section{REFERENCES}

Alexopoulos, C.J., C.W. Mims, \& M. Blackwell. 1996. Introductory Mycology. Fourth Edition. New York: John Wiley \& Sons Inc.

Bensch, K., Braun, U., Groenewald, J.Z. \& Crous, P.W. 2012. The genus Cladosporium. Studies in Mycology, 72, pp. 1-401.

Carris, L. M., Little, C. R., \& Stiles, C. M. 2012. Introduction to Fungi. Plant health Instructor. doi: 10.1094/PHI-I-2012-0426-01.

Ezra, D., Hess, W. M. \& Strobel G. A. 2004. New endophytic isolates of Muscodor albus, a volatile-antibiotic-producing fungus. Microbiology, 150, pp. 4023-4031.

Guarnaccia, V., Groenewald, J. Z., Li, H., Glienke, C., Carstens, E., Hattingh, V., Fourie, P.H., \& Crous, P.W. 2017. First report of Phyllosticta citricarpa and description of two new species, $P$. paracapitalensis and $P$. paracitricarpa, from citrus in Europe. Study Mycology, 87, pp. 161-185.

Nuryadi, W., Anna, R., \& Istiana, P. 2016. Isolasi dan Identifikasi Kapang Endofit dari Pohon Sengon Provenan Kepulauan Solomon Berdasarkan Morfologi dan Molekuler (Analisis rDNA ITS (Internal Transcribed Spacer). Jurnal Biologi, 5(6), pp. 15-26.

Ribeiro, F.P.C., Fonseca, F.C.S., Reis, I.A., Araújo, I.S., Kamida, H.M., Branco, A., \& Uetanabaro, A.P.T. 2012. Xylariaceae Endophytic Fungi Metabolites Against Salmonella. In Book Salmonella - A Diversified Superbug, Brazil, pp. 120-138.

Song Z., Kennedy G. P., Liew J. F., \& Schilling S. J. 2016. Functional Ecology: Fungal Endophyte as Priority Colonizers initiating Wood Decomposition. UK: John wiley \& Sonts.

Widowati, T., Bustanussalam, Harmastini, S., \& Partomuan, S. 2016. Isolasi dan Identifikasi Kapang Endofit dari Tanaman Kunyit (Curcuma longa L.) Sebagai Penghasil Antioksidan. Biopropal Industri, 7(1), pp. 716.

Živković, S.T., Stojanović, S.D., Balaź, J., \& Gavrilović, V.P. 2007. Characteristics of Phomopsis sp. isolates of plum trees origin. Proc. Nat. Sci., Matica Srpska Novi Sad, 113, pp. 83-91. 